\title{
Moderate and high intensity exercise improves glycaemia, blood pressure and body composition in menopausal women with type 2 diabetes
}

\author{
Exercícios de moderada e alta intensidade melhoram glicemia, pressão arterial e composição
} corporal de mulheres diabéticas do tipo 2 na menopausa

El ejercicio de intensidad moderada y alta mejora la glucemia, la presión arterial y la composición corporal en mujeres menopáusicas con diabetes tipo 2

Pedro Gustavo Machado

ORCID: https://orcid.org/0000-0003-2684-7739

Federal University of Lavras, Brazil

E-mail: pedro96gustavo@gmail.com

Alfredo Melhem Baruqui Junior

ORCID: https://orcid.org/0000-0003-3000-4443

Federal University of Lavras, Brazil

E-mail: alfredobaruqui@oi.com.br

Natália Olveira Bertolini

ORCID: https://orcid.org/0000-0002-5120-6776

University Center of Lavras, Brazil

E-mail: nataliaoliveira@unilavras.edu.br

Nathalia Maria Resende

ORCID: https://orcid.org/0000-0002-1496-5343

Federal University of Lavras, Brazil

E-mail: Nathalia.resende@def.ufla.br

Grazielle Carolina da Silva

ORCID: https://orcid.org/0000-0002-9493-1740

University Center of Lavras, Brazil

E-mail: grazishalom@gmail.com

Aline Carvalho Pereira

ORCID: https://orcid.org/0000-0002-5373-0600

Federal University of Lavras, Brazil

E-mail: aline.pereira@dsa.ufla.br

\begin{abstract}
Post-menopausal women are at high risk of developing type 2 diabetes mellitus (T2DM) and cardiovascular diseases. Regular physical activity is recommended for treatment of chronic diseases. However, there is still no consensus about the intensity and type of exercise. This study aimed to evaluate the effects of combined functional training intensity on the cardiometabolic parameters of post-menopausal women with T2DM. Ninety-eight post-menopausal women with T2DM enrolled in the public health service of a Brazilian municipality were invited to participate in this study. Sixteen volunteers were divided into the moderate (MI) and high intensity (HI) groups. Functional training was performed 3 times a week. Anthropometric data, blood pressure, heart rate (HR), plasma glucose, glycated haemoglobin, total cholesterol, HDL-C, LDL-C and triacylglyceride (TG) levels were measured. Functional training reduced glycated haemoglobin and blood pressure levels and improved body composition in both groups. HI training improved HDL-C and TG levels, although a reduction in LDL-C was observed only in the MI group. Physical training did not modify the other evaluated parameters. The data showed that 8 weeks of functional training, regardless of intensity, is an effective strategy to improve glucose control and promote health benefits in post-menopausal women with T2DM.
\end{abstract}

Keywords: Physical exercise; Quality of life; Cardiometabolic risk factors.

\section{Resumo}

Mulheres na menopausa têm alto risco de desenvolver diabetes mellitus tipo 2 (DM2) e doenças cardiovasculares. A atividade física regular é recomendada para o tratamento de doenças crônicas. Porém, ainda não há consenso sobre a intensidade e tipo de exercício. Este estudo teve como objetivo avaliar os efeitos da intensidade de um treinamento funcional sobre os parâmetros cardiometabólicos de mulheres na pós-menopausa com DM2. Noventa e oito mulheres pós-menopáusicas com DM2, cadastradas no serviço público de saúde de um município brasileiro, foram convidadas a participar deste estudo. Dezesseis voluntários foram divididos em grupos de moderada (MI) e alta intensidade (HI). 
O treinamento funcional foi realizado 3 vezes por semana. Dados antropométricos, pressão arterial, frequência cardíaca (FC) e a concentração plasmática de glicose, hemoglobina glicada, colesterol total, HDL-C, LDL-C e de triacilglicerídeo (TG) foram medidos. O treinamento funcional reduziu os níveis de hemoglobina glicada e de pressão arterial e melhorou a composição corporal em ambos os grupos. O treinamento HI melhorou os níveis plasmáticos de HDL-C e TG, embora uma redução no LDL-C tenha sido observada apenas no MI. O treinamento físico não modificou os demais parâmetros avaliados. Os dados mostraram que 8 semanas de treinamento funcional, independente da intensidade, é uma estratégia eficaz para melhorar o controle glicêmico e promover benefícios à saúde de mulheres na menopausa com DM2.

Palavras-chave: Exercício físico; Qualidade de vida; Fatores de risco cardiometabólico.

\section{Resumen}

Las mujeres posmenopáusicas tienen un alto riesgo de desarrollar diabetes mellitus tipo 2 (DM2) y enfermedades cardiovasculares. Se recomienda la actividad física regular para el tratamiento de enfermedades crónicas. Sin embargo, todavía no hay consenso sobre la intensidad y el tipo de ejercicio. Este estudio tuvo como objetivo evaluar los efectos de la intensidad del entrenamiento funcional combinado sobre los parámetros cardiometabólicos de mujeres posmenopáusicas con DM2. Se invitó a participar en este estudio a 98 mujeres posmenopáusicas con DM2 inscritas en el servicio de salud pública de un municipio brasileño. Dieciséis voluntarios se dividieron en grupos de intensidad moderada (MI) y alta (HI). El entrenamiento funcional se realizó 3 veces por semana. Se midieron datos antropométricos, presión arterial, frecuencia cardíaca (FC) y concentración plasmática de glucosa, hemoglobina glucosilada, colesterol total, HDL-C, LDL-C y triacilglicéridos (TG). El entrenamiento funcional redujo la hemoglobina glucosilada y los niveles de presión arterial y mejoró la composición corporal en ambos grupos. El entrenamiento de HI mejoró los niveles de HDL-C y TG, aunque se observó una reducción en el LDL-C en el grupo MI. El entrenamiento físico no modificó el resto de parámetros evaluados. Los datos mostraron que 8 semanas de entrenamiento funcional, independientemente de la intensidad, es una estrategia eficaz para mejorar el control de la glucosa y promover beneficios para la salud en mujeres posmenopáusicas con DM2.

Palabras clave: Ejercicio físico; Calidad de vida; Factores de riesgo cardiometabólico.

\section{Introduction}

Diabetes mellitus (DM) is one of the most prevalent chronic diseases in the world. According to the International Diabetes Federation (IDF, 2020), 425 million people are affected by the disease. Type 2 diabetes (T2DM) is the most common type of the disease and has been considered a serious health problem with increasing prevalence. This is mainly due to the change in the population's lifestyle, specifically the increased caloric intake and physical inactivity, resulting in a true diabetes epidemic (ADA, 2019).

T2DM is associated with insulin resistance, increased visceral adiposity, obesity and metabolic syndrome (MS). MS is a multifactorial disease including metabolic and cardiovascular disorders (Rochlani et al., 2017). There is a greater prevalence of MS in the postmenopausal period due to hormonal changes and factors associated with the ageing process (Stefanska et al., 2015).

The menopause is characterized by a progressive reduction in oestrogen production, a hormone that has beneficial effects on women's health. The loss of oestrogen compromises the vascular function of women during this period (McEniery, 2020), in addition to putting glucose metabolism at risk (Mauvais-Jarvis, 2017) and increasing the concentration of plasma lipids, especially LDL-c and triglycerides (Monteleone et al., 2018; Zaw et al., 2018) Therefore, post-menopausal women are at high risk of developing T2DM and cardiovascular diseases.

Several chronic diseases, such as T2DM and cardiovascular disease, are successfully treated through regular physical exercise. Physical training is a non-pharmacological strategy to prevent the onset of these diseases (Maillard et al., 2016) as it promotes metabolic and cardiovascular benefits, such as increased lean mass, decreased adipose tissue and serum levels of proinflammatory cytokines, and improvement of the insulin resistance (ADA, 2019; Maillard et al., 2016). The American Diabetes Association (ADA) (ADA, 2019) recommends that patients with T2DM perform regular combined exercise at moderate intensity (MI) and those able to do it at high intensity (HI) to achieve better benefits. Previous studies have also shown that 
physical activity is beneficial in relieving menopausal symptoms (Conceição et al., 2013; Diniz et al., 2018; Maillard et al., 2016). However, there is no consensus in the literature regarding this guidance on the type and intensity of physical exercise.

Therefore, the purpose of this study was to compare the effect of different intensities of functional training with combined aerobic and resistance exercises on cardiometabolic parameters in post-menopausal women with T2DM.

\section{Methods}

\subsection{Sample and ethical aspects}

This is a randomized clinical trial (Escosteguy, 1999) that was approved by the local Human Research Ethics Committee (COEP-UFLA) under number 2442296 and approved in the Brazilian Clinical Trial Registry under registration number RBR-5rb2ps. Post-menopausal women with T2DM attended by the basic health unit (UBS) in Lavras city (Brazil, MG) were invited to participate in several lectures and meetings to better explain the importance of improve glucose control, caring for their health and the project goals.

Initially, 98 women were interested in participating in the project. After signing the Informed Consent Form, the participants answered questionnaires about the state of readiness for physical activity (Par-Q) (Joy \& Pescatello, 2016), level of physical activity (IPAQ) (Puciato et al., 2017), and anamnesis related to their clinical history and interest in participating in the intervention with physical exercise.

The study included women with T2DM in amenorrhea for at least 12 consecutive months, sedentary or not practising regular physical activity (according to WHO criteria) (Diniz et al., 2018) and able to practice physical exercise by the Par-Q. Those who underwent hormone replacement therapy, hysterectomies, smokers or alcoholics were excluded, as well as patients with coronary disease or debilitating diseases. After clinical evaluation, an ergometric test was employed to rule out cardiovascular risk.

\subsection{Combined functional training protocol}

The participants were divided into 2 groups, namely, HI $(\mathrm{n}=10)$ and MI $(\mathrm{n}=14)$, according to their availability to train at fixed hours of 7 or 8 am, respectively. Functional training was supervised by an experienced physical training instructor. The sessions were carried out at UBS São Vicente in 24 sessions of combined exercises, with 3 training sessions per week, lasting 60 minutes each. The intervention was characterized by a functional training protocol combined in a circuit, with resistance exercises for large muscle groups and aerobic exercises. The basis for the protocol was joint dominance and centre stability exercises combined with aerobic exercises (Boyle, 2011).

The individual perception of exercise intensity was monitored by the Rated Perceived Exertion Scale (RPE) after each session and by monitoring the heart rate (HR) during the session subjective effort at the end of each training session. The HR measurement was performed using a frequency meter during the session (Haddad et al., 2017). An HR between 50 and $70 \%$ of the maximum HR (HRmax) was defined as MI training, and above 70\% of the HRmax was defined as HI training (Cadore, 2014).

The participants were instructed to maintain the same eating habits and to not change their medication treatment plan during the entire intervention period.

\subsection{Body composition}

Body composition was assessed by bioimpedanciometry using a Matron BF 907 body composition analyser (United Kingdom). The lean mass, water and body fat percentages were analysed. The participants were instructed to avoid the use of diuretic medications, not perform physical activity and not consume alcohol before the exam. Fasting for at least 4 hours was 
required on the day of the exam. Removal of parts or accessories containing metals was requested during the exam. The same operator performed the analysis before and after the intervention.

\subsection{Cardiovascular data}

After a minimum of 10 resting minutes, the systolic (SBP) and diastolic pressure (DBP) of both limbs were measured with the subject's upper limbs supported on a rigid surface using a Durashock sphygmomanometer (USA) and Littmann Classic III stethoscope (USA). The mean arterial pressure (MAP) was calculated using the formula MAP $=\mathrm{SBP}+(2 \mathrm{x}$ DBP)/3. The HR was monitored by a frequency meter and expressed as beats per minute (bpm).

\subsection{Biochemical analyses}

Blood samples were collected before and until 5 days after the last functional training session. This period was defined for convenience, taking care to avoid the acute effect of the exercise. After a 12-hour fast, blood samples were collected directly in a dry vacuum tube with serum separating gel. Total cholesterol (TC), HDL-C, LDL-C, triacylglyceride (TG) and blood glucose measurements were analysed using colourimetric methods, except LDL-C, which was calculated indirectly (Friedewald et al., 1972). A vacuum tube with EDTA (anticoagulant) was employed to measure glycated haemoglobin (HbAlc), which was performed by high-performance liquid chromatography (HPLC).

\subsection{Data analysis}

All statistical analyses were performed using GraphPad Prism 5.0 software (USA). The results were expressed as the mean \pm standard error (SEM). The normality of the data was tested using the Shapiro-Wilk test, and data were transformed into 1/data when necessary, before the statistical analyses. Two-way analysis of variance (ANOVA) was used to assess the effects of group, time and group $\mathrm{x}$ time interactions. Changes from baseline to the end of the intervention were compared using a $\mathrm{t}$ test. When a significant effect was found, multiple post hoc comparisons were made using the Bonferroni test. Metabolic values at baseline and changes from baseline to the end of were also compared between groups, using the non-parametric the study [delta change: $(8$ weeks-baseline/baseline $) \times 100]$. The level of significance was pre-established at $5 \%$.

\section{Results}

A total of 98 women answered the questionnaires. Some of them were excluded ( 7 were not post-menopausal, 4 were hysterectomized, 5 had a history of previous coronary disease, and 10 practised regular physical activity), and 30 were not interested in participating in physical training. Forty-two women were selected for clinical evaluation and 18 of them were excluded ( 
Research, Society and Development, v. 10, n. 8, e52810817571, 2021

(CC BY 4.0) | ISSN 2525-3409 | DOI: http://dx.doi.org/10.33448/rsd-v10i8.17571

Figure 1). The participants were $57-66$ years old, and the last menstruation occurred approximately 7 years ago, with no difference between the MI and HI groups. 
Figure 1. Flowchart of participants pre-selected for the intervention.

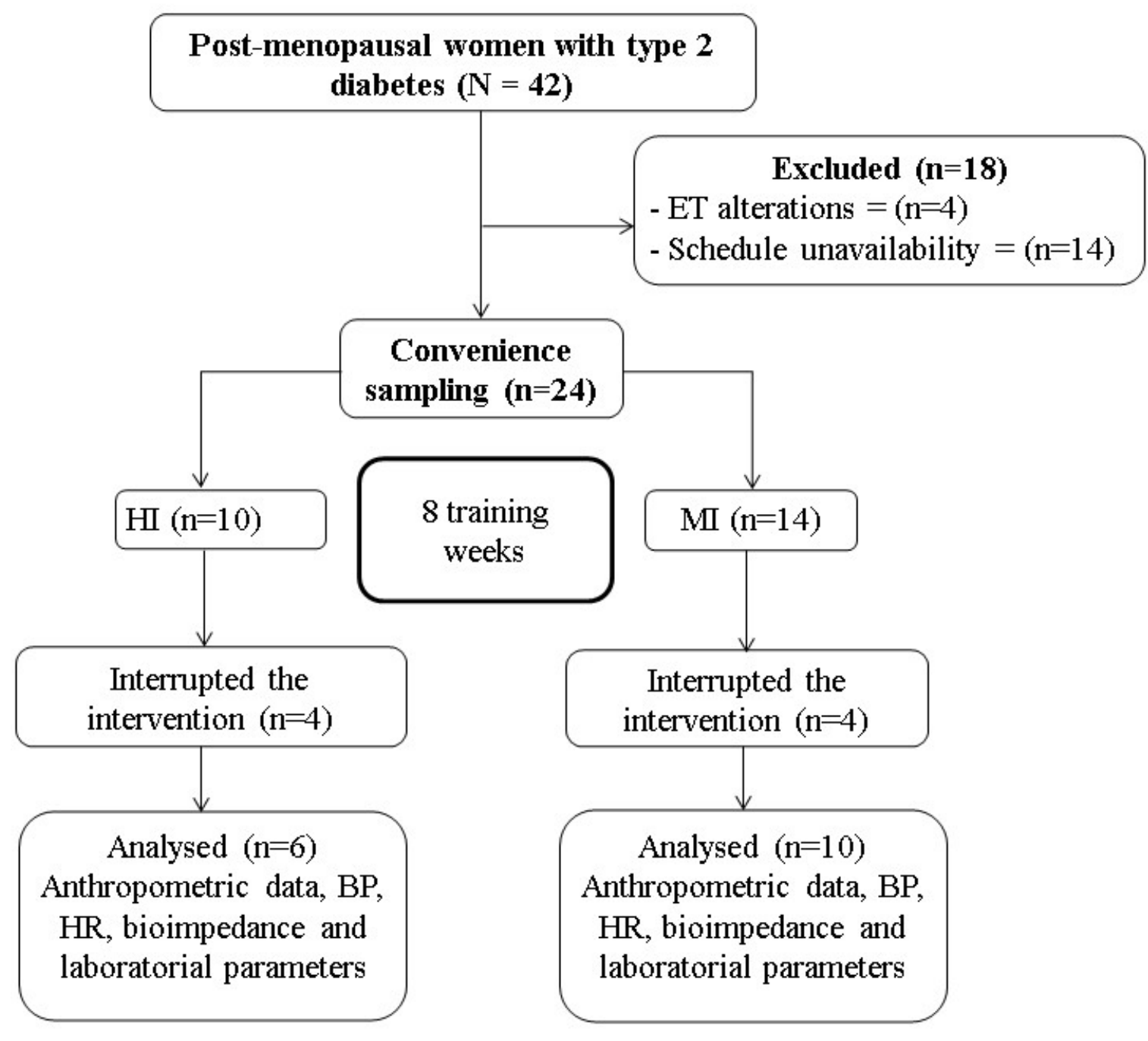

T2DM: type 2 diabetes mellitus; ET: ergometric test; HI: high -intensity; MI: moderate intensity. Source: Authors.

\subsection{Physical exercise intensity assessment}

On a scale of 0 to 10 , the RPE of the MI group (5.68 \pm 0.78$)$ was significantly lower than that of the HI group (RPE $8.67 \pm 0.76 ; \mathrm{p} \leq 0.01)$. The HRmax in the MI group was lower $(121.00 \pm 13.41 \mathrm{bpm})$ than that in the HI group $(151.17 \pm 13.00$ bpm; $\mathrm{p} \leq 0.01)$. Absenteeism was $20 \%$ in MI versus $24 \%$ in $\mathrm{HI}$.

\subsection{Anthropometric data and body composition}

The body weight, body mass index (BMI) and waist circumference (WC) as well as the body composition were similar in the HI and MI groups at baseline. Combined functional training did not alter anthropometric parameters. However, in both groups, there was an improvement in body composition with increased lean mass, increased percentage of water and reduced fat mass after intervention ( $\mathrm{p} \leq 0.05)$, as shown in 1 . The individual values before and after the intervention were also analysed for all the evaluated parameters. However, no significant differences were observed. 
Table 1. Anthropometric data and body composition assessment by bioimpedanciometry before and after 8 weeks of functional training with resistance and aerobic exercise combined in moderate-intensity $(\mathrm{MI} ; \mathrm{n}=10)$ and high-intensity $(\mathrm{HI} ; \mathrm{n}$ $=6)$ conditions.

\begin{tabular}{|c|c|c|c|c|c|c|c|c|c|c|}
\hline & \multicolumn{2}{|c|}{ MI } & \multicolumn{2}{|c|}{$\overline{\mathrm{AI}}$} & \multicolumn{2}{|c|}{ ANOVA $(P)$} & \multirow[b]{2}{*}{ GxT } & \multirow{2}{*}{$\begin{array}{c}\mathrm{MI} \\
\Delta(\%)\end{array}$} & \multirow{2}{*}{$\begin{array}{c}\mathrm{HI} \\
\Delta(\%)\end{array}$} & \multirow[t]{2}{*}{$P$} \\
\hline & Baseline & $8 w$ & Baseline & 8 weeks & $\mathrm{G}$ & $\mathrm{T}$ & & & & \\
\hline Weight (kg) & $74,1 \pm 4,2$ & $73,4 \pm 4,0$ & $66,2 \pm 4,1$ & $65,7 \pm 4,3$ & 0,23 & 0,20 & 0,83 & $-3,1 \pm 1,1$ & $-2,9 \pm 0,7$ & 0,83 \\
\hline BMI $\left(\mathrm{kg} / \mathrm{m}^{2}\right)$ & $30,6 \pm 1,3$ & $30,2 \pm 1,3$ & $27,1 \pm 1,3$ & $27,1 \pm 1,5$ & 0,12 & 0,18 & 0,31 & $-1,9 \pm 0,6$ & $-0,4 \pm 0,9$ & 0,75 \\
\hline $\mathrm{WC}(\mathrm{cm})$ & $97,8 \pm 3,6$ & $96,4 \pm 3,5$ & $94,8 \pm 4,3$ & $94,3 \pm 4,4$ & 0,66 & 0,11 & 0,45 & $-1,3 \pm 0,8$ & $-0,5 \pm 0,4$ & 0,77 \\
\hline$\%$ Total Fat & $42,8 \pm 1,3$ & $40,9 \pm 1,3$ & $41,2 \pm 3,8$ & $39,4 \pm 3,7$ & 0,65 & $\mathbf{0 , 0 0 * *}$ & 0,89 & $-0,4 \pm 0,1$ & $-0,4 \pm 0,1$ & 0,89 \\
\hline$\%$ Lean Mass & $57,2 \pm 1,3$ & $59,1 \pm 1,3$ & $58,8 \pm 3,8$ & $60,6 \pm 3,7$ & 0,65 & $\mathbf{0 , 0 0 * *}$ & 0,89 & $0,5 \pm 0,1$ & $0,3 \pm 0,1$ & 0,49 \\
\hline$\%$ Water & $41,8 \pm 1,0$ & $43,3 \pm 0,9$ & $43,3 \pm 2,8$ & $44,4 \pm 2,7$ & 0,61 & $\mathbf{0 , 0 1}{ }^{*}$ & 0,62 & $0,8 \pm 0,2$ & $0,2 \pm 0,1$ & 0,62 \\
\hline
\end{tabular}

Data are the mean \pm SEM. Statistically significant results $(\mathrm{p} \leq 0.05)$ are shown in bold. BMI: body mass index; WC: waist circumference; MI: moderate intensity; HI: high intensity; G: group effect; T: effect of time; GxT: effect of group and time interaction; $\Delta(\%)$ : changes from baseline to the end ( 8 weeks-baseline/baseline) $\times 100 . * \mathrm{p} \leq 0.05, * * \mathrm{p} \leq 0.01$. Source: Authors.

\subsection{Blood pressure levels, HR and biochemical data}

Blood pressure levels, HR and biochemical parameters before training were similar between the HI and MI groups ( 
Table 2). The combined functional training reduced SBP, DBP and MAP in both groups, without differences between the groups. Although there were no differences in fasting blood glucose values, there was an improvement in HbAlc in both groups.

The intensity of the combined functional training promoted different changes in the lipid profile. An increase in HDLC was observed only in the HI group. Although there was no change in averaged TG levels between HI and MI, the difference between the values at baseline and after intervention was significantly reduced only in the HI group. On the other hand, LDL-C was significantly reduced in the MI group. The intensity of functional training in this study did not modify the total cholesterol/high-density lipoprotein ratio (TC/HDL). 
Table 2. Blood pressure, heart rate, plasma lipids, fasting glycaemia, and glycated haemoglobin before and after 8 weeks of functional training with resistance and aerobic exercise combined in moderate-intensity $(\mathrm{MI} ; \mathrm{n}=10)$ and high-intensity $(\mathrm{HI} ; \mathrm{n}$ $=6)$ conditions.

\begin{tabular}{|c|c|c|c|c|c|c|c|c|c|c|}
\hline & \multicolumn{2}{|c|}{ MI } & \multicolumn{2}{|c|}{ AI } & \multicolumn{3}{|c|}{$\operatorname{ANOVA}(P)$} & \multirow{2}{*}{$\frac{\mathrm{MI}}{\Delta(\%)}$} & \multirow{2}{*}{$\frac{\mathrm{AI}}{\Delta(\%)}$} & \multirow[t]{2}{*}{$P$} \\
\hline & Baseline & 8 Weeks & Baseline & 8 Weeks & G & $\mathrm{T}$ & GxT & & & \\
\hline $\begin{array}{l}\text { SBP } \\
(\mathrm{mmHg})\end{array}$ & $123,0 \pm 6,7$ & $117,0 \pm 6,5$ & $125,0 \pm 5,00$ & $115,0 \pm 5,6$ & 1,00 & $\mathbf{0 , 0 0 * *}$ & 0,42 & $-4,5 \pm 2,7$ & $-8,6 \pm 2,1$ & 0,42 \\
\hline $\begin{array}{l}\text { DBP } \\
(\mathrm{mmHg})\end{array}$ & $76,0 \pm 4,0$ & $72,0 \pm 2,9$ & $80,0 \pm 00$ & $71,8 \pm 3,1$ & 0,68 & $0,01^{*}$ & 0,32 & $\begin{array}{l}-4,2 \\
\pm 3,5\end{array}$ & $\begin{array}{l}-10,4 \\
\pm 3,8\end{array}$ & 0,32 \\
\hline $\begin{array}{l}\text { MAP } \\
(\mathrm{mmHg})\end{array}$ & $93,6 \pm 4,9$ & $88,9 \pm 3,8$ & $95,0 \pm 1,7$ & $86,1 \pm 3,6$ & 0,10 & $\mathbf{0 , 0 2 *}$ & 0,29 & $\begin{array}{l}-4,3 \\
\pm 3,0\end{array}$ & $-9,4 \pm 2,7$ & 0,35 \\
\hline $\begin{array}{l}\text { HR } \\
\text { (bpm) }\end{array}$ & $81,6 \pm 4,7$ & $74,0 \pm 4,8$ & $80,0 \pm 8,2$ & $80,7 \pm 7,4$ & 0,78 & 0,18 & 0,31 & $\begin{array}{l}-7,6 \\
\pm 4,4\end{array}$ & $2,0 \pm 5,0$ & 0,22 \\
\hline $\begin{array}{l}\text { TC } \\
(\mathrm{mg} / \mathrm{dL})\end{array}$ & $168,3 \pm 8,5$ & $161,9 \pm 10,7$ & $191,5 \pm 13,5$ & $199,3 \pm 11,2$ & 0,07 & 0,86 & 0,10 & $1,6 \pm 6,4$ & $4,7 \pm 2,3$ & 0,09 \\
\hline $\begin{array}{l}\text { HDL } \\
(\mathrm{mg} / \mathrm{dL})\end{array}$ & $42,8 \pm 2,7$ & $42,1 \pm 2,5$ & $47,3 \pm 5,3$ & $50,2 \pm 5,2$ & 0,25 & 0,12 & $0,02^{*}$ & $0,0 \pm 2,2$ & $4,4 \pm 4,0^{*}$ & $0,03^{*}$ \\
\hline $\begin{array}{l}\text { LDL } \\
(\mathrm{mg} / \mathrm{dL})\end{array}$ & $98,0 \pm 8,4$ & $86,4 \pm 8,1$ & $109,0 \pm 14,2$ & $119,5 \pm 12,6$ & 0,21 & 0,71 & $0,01^{*}$ & $\begin{array}{c}-8,5 \\
\pm 4,7^{* *}\end{array}$ & $12,5 \pm 6,1$ & $0,00^{* * *}$ \\
\hline $\begin{array}{l}\text { TG } \\
(\mathrm{mg} / \mathrm{dL})\end{array}$ & $149,2 \pm 3,0$ & $\begin{array}{l}162,3 \\
\pm 17,6\end{array}$ & $\begin{array}{l}182,8 \\
\pm 28,4\end{array}$ & $\begin{array}{l}153,5 \\
\pm 29,2\end{array}$ & 0,68 & 0,14 & 0,06 & $\begin{array}{l}10,8 \\
\pm 8,8\end{array}$ & $\begin{array}{c}- \\
19,3 \pm 5,2^{*}\end{array}$ & $0,02^{*}$ \\
\hline TC/HDL & $4,07 \pm 0,1$ & $4,11 \pm 0,3$ & $4,0 \pm 0,5$ & $3,95 \pm 0,5$ & 0,87 & 0,77 & 0,55 & $1,2 \pm 3,4$ & $1,1 \pm 5,7$ & 0,55 \\
\hline $\begin{array}{l}\text { FBG } \\
(\mathrm{mg} / \mathrm{dL})\end{array}$ & $146,6 \pm 20,3$ & $\begin{array}{l}153,9 \\
\pm 26,8\end{array}$ & $\begin{array}{l}147,7 \\
\pm 11,2\end{array}$ & $\begin{array}{l}168,3 \\
\pm 20,9\end{array}$ & 0,38 & 0,69 & 0,44 & $\begin{array}{c}4,1 \\
\pm 10,0\end{array}$ & $\begin{array}{c}17,7 \\
\pm 18,6\end{array}$ & 0,67 \\
\hline $\begin{array}{l}\text { HbAlc } \\
(\%)\end{array}$ & $9,4 \pm 2,0$ & $7,9 \pm 1,0$ & $8,6 \pm 0,9$ & $7,8 \pm 0,5$ & 0,70 & $0,02^{*}$ & 0,97 & $\begin{array}{l}-4,9 \\
\pm 1,7\end{array}$ & $-7,2 \pm 5,4$ & 0,91 \\
\hline
\end{tabular}

Data are the mean \pm SEM. Statistically significant results $(\mathrm{P} \leq 0.05)$ are shown in bold. MI: moderate intensity; HI: high intensity; G: group effect; T: time effect; GxT: effect of group and time interaction; $\Delta(\%)$ : changes from baseline to the end ( 8 weeks-baseline/baseline) $\times 100$; SBP: systolic blood pressure; DBP: diastolic blood pressure; MAP: mean arterial pressure; HR: heart rate; TC: total cholesterol; HDL: highdensity lipoprotein; LDL: low-density lipoprotein; TG: triglycerides; TC/HDL: total cholesterol to high-density lipoprotein ratio; FBG: fasting blood glucose; HbAlc: glycated haemoglobin. Source: Authors.

\section{Discussion}

In just 8 weeks, combined functional training promoted cardiometabolic benefits in T2DM women at menopause, confirming the efficiency of this treatment in this population. However, despite the benefits described in the literature, there is still great resistance to changing life habits. This was evidenced by the large number of women who were initially interested in the study $(\mathrm{n}=98)$ but not in physical training $(\mathrm{n}=30)$, as well as by the small number of participants who remained throughout the 8 weeks in the training. The fact that only a small number of volunteers completed the training was one of the main limitations of this study. However, this is frequently observed in clinical trials involving physical activity and evidence of the low adherence of the population to physical and sports practice, corroborating the high rates of sedentary lifestyle in the current world (Balducci et al., 2019; Cooper et al., 2012). Due to the health benefits and improvement in quality of life, it is 
necessary to encourage the regular practice of physical exercises (Conceição et al., 2013; Maillard et al., 2016; Schroeder et al., 2019), mainly in populations at high cardiovascular risk, such as women with T2DM in menopause (Myers et al., 2013).

Menopause increases cardiovascular and metabolic risk, in addition to frequently leading to emotional changes that can compromise treatment and worsen T2DM (Clegg et al., 2017; Diniz et al., 2018). The practice of regular physical exercise is an important strategy in this phase of a woman's life, with several benefits depending on the type of exercise (Maillard et al., 2016).

Different types of physical training can result in different effects, according to specific characteristics (Bacchi et al., 2012; Maillard et al., 2016; Shimojo et al., 2018). These variables are not entirely clear, and there is no consensus in the literature regarding the intensity, type, and volume of physical exercise that promotes greater benefit in certain conditions (Bacchi et al., 2012). In this study, a functional training was used to assess the effects of different intensities in postmenopausal women with T2DM.

Combined functional training for 8 weeks reduced fat mass and increased lean mass, regardless of the intensity used. These changes in body composition were previously evidenced in interventions of 14 weeks of moderate-intensity walking (Giannopoulou et al., 2005), and in interventions of 16 weeks with resistance and combined exercises in women with T2DM in menopause (Conceição et al., 2013; Cuff et al., 2003). Even with a shorter intervention time (8 weeks), the protocol used in this study improved women's body composition. However, it was not efficient in promoting weight loss since this relationship becomes subjective with regular practice of physical exercise because the gain of muscle mass is also a factor in the change in body weight. Furthermore, there was no caloric restriction to analyse the balance of caloric intake/expenditure.

Most of the participants underwent pharmacological treatment to arterial hypertension control (67\% in the MI group and $70 \%$ in the $\mathrm{HI}$ group), showing normal blood pressure levels at the beginning of the study. The intervention was able to reduce the values of SBP, DBP, and MAP, regardless of the intensity of the exercise. These results corroborate findings that showed an improvement in the DBP of overweight and hypertensive individuals in just 8 weeks of combined physical exercise (Nascimento et al., 2017; Schroeder et al., 2019). Additionally, another study performed combined exercises for 12 weeks in post-menopausal hypertensive women and resulted in a decrease in SBP (Son et al., 2016). The improvement in these parameters under conditions similar to our study suggests that physical exercise is an efficient strategy to prevent or treat hypertension and other cardiovascular diseases (CVD).

Furthermore, combined functional training, regardless of intensity, showed improvement in glycaemic control. The fasting blood glucose (FBG) were not altered, however, the functional training reduced HbA1c levels. Similarly, a study with continuous low-intensity physical training for 6 months was able to significantly reduce the levels of HbAlc more than moderate-to high-intensity exercise training without reducing FBG levels (Hansen et al., 2009), which suggest that HbA1c is a more reliable parameter of glycaemic control. These disparities between FBG and HbA1c may be due to several factors (Liu et al., 2015). FBG provides an acute measurement of glycaemia, whereas $\mathrm{HbAlc}$ is stable and reflects glycaemic exposure over the last 8 to 12 weeks (Nathan et al., 2007; Vistisen et al., 2018). Previous studies suggested that HbA1c is related to an inflammatory grade, independent of FBG (Jiang et al., 2014; Liu et al., 2015). These observations contribute to explaining the significant positive relationship between high HbA1c levels and the risk of CVD (Liu et al., 2015; Vistisen et al., 2018). There is evidence that regular practice of physical activity for at least 8 weeks reduces $\mathrm{HbAlc}$ by approximately $0.66 \%$, similar to what is achieved with the use of some classes of oral hypoglycaemic agents (ADA, 2019). This reduction is significant as it can prevent chronic complications associated with diabetes. For each percentage point reduction in HbAlc, there is a $37 \%$ decrease in microvascular complications, $14 \%$ in fatal and non-fatal acute myocardial infarction and $21 \%$ in all diabetesrelated deaths (Stratton et al., 2000). 
In addition to diabetes, CVD is a multifactorial disease with correlated risk factors that include dyslipidaemia. In this study, combined functional training also promoted benefits in the lipid profile of post-menopausal women with T2DM, and the effects were dependent on exercise intensity. Previously, it was observed that combined physical exercise showed better results on the lipid profile in patients with T2DM, representing one of the most effective procedures to reduce cardiovascular risk (Schwingshackl et al., 2014). The mechanisms responsible for this improvement are not fully understood, but there appears to be greater oxidation of lipids in skeletal muscle, which reduces plasma lipid levels (Alvarez et al., 2018).

TC levels were not altered by training, which can be explained by the short duration of the intervention, as previously suggested in a study with obese adults during the same period ( 8 weeks) of combined training (Schroeder et al., 2019). Similarly, other studies showed that combined physical training for 8-16 weeks did not change TC levels in post-menopausal women (Christos et al., 2009; Maillard et al., 2016; Rossi et al., 2016). On the other hand, only 6 weeks of aerobic or resistance training at moderate intensity was sufficient to reduce TC in patients with T2DM of both sexes aged 45 to 50 years (Farias et al., 2015). In fact, several factors can interfere with TC levels. The reduction in TC due to physical activity is directly proportional to baseline levels and the volume of training (Alvarez et al., 2018). In our study, the baseline TC levels were within the normal range, as most participants used lipid-lowering medication, which can contribute to justifying the result. Indeed, a determining factor in the response to exercise is genetic characteristics. Although a molecular study has not been carried out, there are dysfunction that can interfere with the response of lipids to physical training on diabetes' people (Srivastava, 2018), justifying the different responses observed among studies.

Within the parameters that characterize the lipid profile, high levels of LDL-C are associated with a high cardiovascular risk, mainly due to the atherogenic potential of this lipoprotein (Grundy et al., 2019). We observed a reduction in LDL-C only in the MI group. High-intensity exercises primarily use carbohydrates as the main source of energy, while at moderate intensity, there is greater lipid oxidation due to the transition in the energy pathways, which could explain this reduction in LDL-C in the MI group (McGarrah et al., 2016).

In addition, our data showed no significant difference in HDL-C levels in the MI group. On the other hand, in the HI group, HDL-C increased after the intervention. An interesting observation is that baseline LDL-C values in the HI group is above the recommendation (Faludi et al., 2017; Grundy et al., 2019), and these high lipoprotein levels could result in more sensitivity, possibly explaining the increased HDL-C only in HI group. Controlled levels of HDL-C are associated with cardiovascular protection, as this lipoprotein is involved in the reverse transport of cholesterol and in anti-inflammatory, antithrombogenic, and vasodilatory effects (Choudhury et al., 2004). Increasing HDL-C is recommended, especially if LDL-C levels are high. This increase is considered the most commonly observed effect on the lipid profile following a physical activity program (Srivastava, 2018). Its decrease predisposes to the risk of the development of CVD (Rader \& Hovingh, 2014). In addition to individual characteristics, another justification for the increased HDL-C only in the HI group is the higher energy expenditure. However, in our study, the calculation of energy expenditure was not performed due to the circuit training protocol and combined exercises. An important observation is that some studies have shown that in diabetic patients, HDL-C is dysfunctional (Srivastava, 2018); therefore, it is more relevant to control blood glucose than to increase HDL-C levels. The results of this study showed improvement in glycaemic control in both groups, suggesting more significant protection than the increase in HDL-C.

With respect to the lipid profile, serum TG levels should be considered, whose elevation predisposes to the risk of the development of MS (Grundy et al., 2019) and CVD (Faludi et al., 2017). In this study, a reduction in TG levels was observed only in the HI group. Similar to the observation of high baseline LDL-C, baseline TG values were above the desired levels in the HI group compared to the MI group, which may have contributed to greater exercise sensitivity and a significant reduction in this parameter only in the HI group. Some studies have suggested the influence of exercise modality and intensity (Maillard 
et al., 2016; Schwingshackl et al., 2014) on lipaemia; however, divergent results have already been observed. Women with MS or post-menopausal women did not show a reduction in TG after 16 weeks of moderate- or high-intensity aerobic exercise (Irving et al., 2008). Even a 6-month period of training in different modalities was not enough to reduce TG in patients with T2DM (Lesser et al., 2016). On the other hand, some studies have shown improvement in this parameter after combined aerobic and resistance training or with high-intensity training (Alvarez et al., 2018; Ho et al., 2012). It was observed that the post-menopausal women who presented a reduction in TG after physical exercise were those who had elevated HDL-C, corroborating our study (Diniz et al., 2018). Another important factor interfering with TG levels is diet or eating habits (Albu et al., 2010), which were not evaluated in this study.

Despite the increase in HDL-C and reduction in TG levels in the HI group and the reduction in LDL-C in the MI group, there was no reduction in TC in any of the evaluated groups, making the final interpretation difficult. However, clinical studies have shown that the ratio between TC/HDL-C and LDL-C/HDL-C is a better indicator of cardiovascular risk than the isolated assessment of the values of TC, LDL-C, and HDL-C (Millán et al., 2009). Despite the differences observed in isolated lipid parameters, there was no significant difference in these indexes, suggesting that the conditions used in this study were not sufficient to improve lipaemia and reduce the risk of cardiovascular disease in these women.

In conclusion, 8 weeks of functional training with combined aerobic and resistance exercise, both at high and at moderate intensity, was sufficient to promote health benefits for post-menopausal type 2 diabetic women. There was a significant improvement in glycaemic control and body composition, in addition to a reduction in blood pressure values. The results obtained suggest that the intensity of physical training can result in different beneficial effects on isolated plasma lipids, although it did not modify the cardiovascular risk of these women. It was not evaluated the balance of caloric intake/expenditure and it is not clear whether the determining factor for cardiometabolic effects is the total energy expenditure or the intensity of the exercise itself. Therefore, maintaining energy expenditure and varying the intensity of physical training is an important point to be clarified in later studies.

\section{Conclusion}

Altogether, these results suggest that the practice of functional training with combined physical exercise, regardless of intensity, is an important strategy to prevent health complications in post-menopausal women with T2DM. Lifestyle changes can improve the quality of life, in addition to reducing the cost and assisting the drug treatment of diabetes.

Maintenance of energy expenditure for a longer period of training can result in additional benefits for health in general, being an important point to be clarified in further studies.

\section{Acknowledgments}

The authors are grateful for the collaboration of all the participants of this study and also for the support given by Lavras City Council and UFLA in carrying out this research. The study was registered in the Brazilian Clinical Trial Registry under registration number RBR-5rb2ps.

\section{References}

ADA, A. D. A. (2019). Introduction: Standards of Medical Care in Diabetes-2019. Diabetes Care, 42(Supplement 1), S1-S2. https://doi.org/10.2337/dc19Sint01

Albu, J. B., Heilbronn, L. K., Kelley, D. E., Smith, S. R., Azuma, K., Berk, E. S., Xavier Pi-Sunyer, F., \& Ravussin, E. (2010). Metabolic changes following a 1 -year diet and exercise intervention in patients with type 2 diabetes. Diabetes, 59(3), 627-633. https://doi.org/10.2337/db09-1239

Alvarez, C., Ramirez-Campillo, R., Martinez-Salazar, C., Castillo, A., Gallardo, F., \& Ciolac, E. (2018). High-Intensity Interval Training as a Tool for Counteracting Dyslipidemia in Women. International Journal of Sports Medicine, 39(05), 397-406. https://doi.org/10.1055/s-0044-100387 
Bacchi, E., Negri, C., Zanolin, M. E., Milanese, C., Faccioli, N., Trombetta, M., Zoppini, G., Cevese, A., Bonadonna, R. C., Schena, F., Bonora, E., Lanza, M., \& Moghetti, P. (2012). Metabolic effects of aerobic training and resistance training in type 2 diabetic subjects: A randomized controlled trial (the RAED2 study). Diabetes Care, 35(4), 676-682. https://doi.org/10.2337/dc11-1655

Balducci, S., D’Errico, V., Haxhi, J., Sacchetti, M., Orlando, G., Cardelli, P., Vitale, M., Bollanti, L., Conti, F., Zanuso, S., Lucisano, G., Nicolucci, A., \& Pugliese, G. (2019). Effect of a Behavioral Intervention Strategy on Sustained Change in Physical Activity and Sedentary Behavior in Patients with Type 2 Diabetes: The IDES-2 Randomized Clinical Trial. JAMA - Journal of the American Medical Association, 321(9), 880-890. https://doi.org/10.1001/jama.2019.0922

Boyle, M. (2011). Advances in functional training (1st ed.). On Target Publications.

Cadore, E. (2014). Strength and Endurance Training Prescription in Healthy and Frail Elderly. Aging and Disease, 5(3), 183. https://doi.org/10.14336/AD.2014.0500183

Choudhury, R. P., Rong, J. X., Trogan, E., Elmalem, V. I., Dansky, H. M., Breslow, J. L., Witztum, J. L., Fallon, J. T., \& Fisher, E. A. (2004). High-density lipoproteins retard the progression of atherosclerosis and favorably remodel lesions without suppressing indices of inflammation or oxidation. Arteriosclerosis, Thrombosis, and Vascular Biology, 24(10), 1904-1909. https://doi.org/10.1161/01.ATV.0000142808.34602.25

Christos, Z. E., Tokmakidis, S. P., Volaklis, K. A., Kotsa, K., Touvra, A. M., Douda, E., \& Yovos, I. G. (2009). Lipoprotein profile, glycemic control and physical fitness after strength and aerobic training in post-menopausal women with type 2 diabetes. European Journal of Applied Physiology, 106(6), 901907. https://doi.org/10.1007/s00421-009-1078-6

Clegg, D., Hevener, A. L., Moreau, K. L., Morselli, E., Criollo, A., Van Pelt, R. E., \& Vieira-Potter, V. J. (2017). Sex Hormones and Cardiometabolic Health: Role of Estrogen and Estrogen Receptors. Endocrinology, 158(5), 1095-1105. https://doi.org/10.1210/en.2016-1677

Conceição, M., Bonganha, Vechin, Berton, LixandrÃo, Damas Nogueira, F. R., Souza, Chacon-mikahil, \& Libardi. (2013). Sixteen weeks of resistance training can decrease the risk of metabolic syndrome in healthy postmenopausal women. Clinical Interventions in Aging, 8 , 1221. https://doi.org/10.2147/CIA.S44245

Cooper, A. R., Sebire, S., Montgomery, A. A., Peters, T. J., Sharp, D. J., Jackson, N., Fitzsimons, K., Dayan, C. M., \& Andrews, R. C. (2012). Sedentary time, breaks in sedentary time and metabolic variables in people with newly diagnosed type 2 diabetes. Diabetologia, 55(3), 589-599. https://doi.org/10.1007/s00125-011-2408-x

Cuff, D. J., Meneilly, G. S., Martin, A., Ignaszewski, A., Tildesley, H. D., \& Frohlich, J. J. (2003). Effective Exercise Modality to Reduce Insulin Resistance in Women With Type 2 Diabetes. Diabetes Care, 26(11), 2977-2982. https://doi.org/10.2337/diacare.26.11.2977

Diniz, T. A., Rossi, F. E., Fortaleza, A. C. S., Neves, L. M., Christofaro, D. G. D., Buonani, C., Lira, F. S., Campos, E. Z., Prado, W. L. do, \& Freitas Jr, I. F. (2018). Changes in HDL-c concentrations after 16 weeks of combined training in postmenopausal women: characteristics of positive and negative responders Applied Physiology, Nutrition, and Metabolism, 43(1), 38-44. https://doi.org/10.1139/apnm-2017-0294

Escosteguy, C. C. (1999). Tópicos Metodológicos e Estatísticos em Ensaios Clínicos Controlados Randomizados. Arq Bras Cardiol, $72\left(n^{\circ} 2\right), 139-143$.

Faludi, A., Izar, M., Saraiva, J., Chacra, A., Bianco, H., Afiune Neto, A., Bertolami, A., Pereira, A., Lottenberg, A., Sposito, A., Chagas, A., Casella-Filho, A., Simão, A., Alencar Filho, A., Caramelli, B., Magalhães, C., Magnoni, D., Negrão, C., Ferreira, C., ... Salgado Filho, W. (2017). Atualização da diretriz brasileira de dislipidemias e prevenção da aterosclerose - 2017. Arquivos Brasileiros de Cardiologia, 109(1), 1-92. https://doi.org/10.5935/abc.20170121

Farias, T. Y., Santos-Lozano, A., Urra, P. S., \& Cristi-Montero, C. (2015). Efectos del entrenamiento y el desentrenamiento físico sobre la hemoglobina glucosilada, la glucemia y el perfil lipídico en diabéticos tipo II. Nutricion Hospitalaria, 32(4), 1729-1734. https://doi.org/10.3305/nh.2015.32.4.9341

Friedewald, W. T., Levy, R. I., \& Fredrickson, D. S. (1972). Estimation of the concentration of low-density lipoprotein cholesterol in plasma, without use of the preparative ultracentrifuge. Clinical Chemistry, 18(6), 499-502. http://www.ncbi.nlm.nih.gov/pubmed/4337382

Giannopoulou, I., Ploutz-Snyder, L. L., Carhart, R., Weinstock, R. S., Fernhall, B., Goulopoulou, S., \& Kanaley, J. A. (2005). Exercise Is Required for Visceral Fat Loss in Postmenopausal Women with Type 2 Diabetes. The Journal of Clinical Endocrinology \& Metabolism, 90(3), 1511-1518. https://doi.org/10.1210/jc.2004-1782

Grundy, S. M., Stone, N. J., Bailey, A. L., Beam, C., Birtcher, K. K., Blumenthal, R. S., Braun, L. T., de Ferranti, S., Faiella-Tommasino, J., Forman, D. E., Goldberg, R., Heidenreich, P. A., Hlatky, M. A., Jones, D. W., Lloyd-Jones, D., Lopez-Pajares, N., Ndumele, C. E., Orringer, C. E., Peralta, C. A., \& Yeboah, J. (2019). 2018 AHA/ACC/AACVPR/AAPA/ABC/ACPM/ADA/AGS/APhA/ASPC/NLA/PCNA Guideline on the Management of Blood Cholesterol: A Report of the American College of Cardiology/American Heart Association Task Force on Clinical Practice Guidelines. Journal of the American College of Cardiology, 73(24), e285-e350. https://doi.org/10.1016/j.jacc.2018.11.003

Haddad, M., Stylianides, G., Djaoui, L., Dellal, A., \& Chamari, K. (2017). Session-RPE Method for Training Load Monitoring: Validity, Ecological Usefulness, and Influencing Factors. Frontiers in Neuroscience, 11 (NOV). https://doi.org/10.3389/fnins.2017.00612

Hansen, D., Dendale, P., Jonkers, R. A. M., Beelen, M., Manders, R. J. F., Corluy, L., Mullens, A., Berger, J., Meeusen, R., \& van Loon, L. J. C. (2009). Continuous low- to moderate-intensity exercise training is as effective as moderate- to high-intensity exercise training at lowering blood HbA1c in obese type 2 diabetes patients. Diabetologia, 52(9), 1789-1797. https://doi.org/10.1007/s00125-009-1354-3

Ho, S. S., Dhaliwal, S. S., Hills, A. P., \& Pal, S. (2012). The effect of 12 weeks of aerobic, resistance or combination exercise training on cardiovascular risk factors in the overweight and obese in a randomized trial. BMC Public Health, 12(1), 704. https://doi.org/10.1186/1471-2458-12-704

IDF, I. D. F. (2020). IDF Diabetes Atlas. 2020. https://www.idf.org/e-library/epidemiology-research/diabetes-atlas

Irving, B. A., Davis, C. K., Brock, D. W., Weltman, J. Y., Swift, D., Barrett, E. J., Gaesser, G. A., \& Weltman, A. (2008). Effect of Exercise Training Intensity on Abdominal Visceral Fat and Body Composition. Medicine \& Science in Sports \& Exercise, 40(11), 1863-1872. 
https://doi.org/10.1249/MSS.0b013e3181801d40

Jiang, H., Yan, W.-H., Li, C.-J., Wang, A.-P., Dou, J.-T., \& Mu, Y.-M. (2014). Elevated White Blood Cell Count Is Associated with Higher Risk of Glucose Metabolism Disorders in Middle-Aged and Elderly Chinese People. International Journal of Environmental Research and Public Health, 11(5), 5497-5509. https://doi.org/10.3390/ijerph110505497

Joy, E. A., \& Pescatello, L. S. (2016). Pre-exercise screening: role of the primary care physician. Israel Journal of Health Policy Research, 5(1), 29. https://doi.org/10.1186/s13584-016-0089-0

Lesser, I. A., Guenette, J. A., Hoogbruin, A., Mackey, D. C., Singer, J., Gasevic, D., \& Lear, S. A. (2016). Association between exercise-induced change in body composition and change in cardiometabolic risk factors in postmenopausal South Asian women. Applied Physiology, Nutrition, and Metabolism = Physiologie Appliquee, Nutrition et Metabolisme, 41(9), 931-937. https://doi.org/10.1139/apnm-2016-0082

Liu, S., Hempe, J. M., McCarter, R. J., Li, S., \& Fonseca, V. A. (2015). Association between Inflammation and Biological Variation in Hemoglobin A1c in U.S. Nondiabetic Adults. The Journal of Clinical Endocrinology \& Metabolism, 100(6), 2364-2371. https://doi.org/10.1210/jc.2014-4454

Maillard, F., Rousset, S., Pereira, B., Traore, A., de Pradel Del Amaze, P., Boirie, Y., Duclos, M., \& Boisseau, N. (2016). High-intensity interval training reduces abdominal fat mass in postmenopausal women with type 2 diabetes. Diabetes and Metabolism, 42(6), 433-441. https://doi.org/10.1016/j.diabet.2016.07.031

Mauvais-Jarvis, F. (2017). Menopause, estrogens, and glucose homeostasis in women. Advances in Experimental Medicine and Biology, 1043, 217-225. https://doi.org/10.1007/978-3-319-70178-3_11

McEniery, C. M. (2020). Transitioning the Menopause. Arteriosclerosis, Thrombosis, and Vascular Biology, 40(4), 850-852. https://doi.org/10.1161/ATVBAHA.120.313980

McGarrah, R. W., Slentz, C. A., \& Kraus, W. E. (2016). The Effect of Vigorous- Versus Moderate-Intensity Aerobic Exercise on Insulin Action. Current Cardiology Reports, 18(12), 117. https://doi.org/10.1007/s11886-016-0797-7

Millán, J., Pintó, X., Muñoz, A., Zúñiga, M., Rubiés-Prat, J., Pallardo, L. F., Masana, L., Mangas, A., Hernández-Mijares, A., González-Santos, P., Ascaso, J. F., \& Pedro-Botet, J. (2009). Lipoprotein ratios: Physiological significance and clinical usefulness in cardiovascular prevention. Vascular Health and Risk Management, 5, 757. https://doi.org/10.2147/VHRM.S6269

Monteleone, P., Mascagni, G., Giannini, A., Genazzani, A. R., \& Simoncini, T. (2018). Symptoms of menopause - global prevalence, physiology and implications. Nature Reviews Endocrinology, 14(4), 199-215. https://doi.org/10.1038/nrendo.2017.180

Myers, V. H., McVay, M. A., Brashear, M. M., Johannsen, N. M., Swift, D. L., Kramer, K., Harris, M. N., Johnson, W. D., Earnest, C. P., \& Church, T. S. (2013). Exercise training and quality of life in individuals with type 2 diabetes. Diabetes Care, 36(7), 1884-1890. https://doi.org/10.2337/dc12-1153

Nascimento, L. S., Santos, A. C., Lucena, J. M. S., Silva, L. G. O., Almeida, A. E. M., \& Brasileiro-Santos, M. S. (2017). Acute and chronic effects of aerobic exercise on blood pressure in resistant hypertension: Study protocol for a randomized controlled trial. Trials, 18(1). https://oi.org/10.1186/s13063-017-1985-5

Nathan, D. M., Turgeon, H., \& Regan, S. (2007). Relationship between glycated haemoglobin levels and mean glucose levels over time. Diabetologia, 50(11), 2239-2244. https://doi.org/10.1007/s00125-007-0803-0

Puciato, D., Borysiuk, Z., \& Rozpara, M. (2017). Quality of life and physical activity in an older working-age population. Clinical Interventions in Aging, 12, 1627-1634. https://doi.org/10.2147/CIA.S144045

Rader, D. J., \& Hovingh, G. K. (2014). HDL and cardiovascular disease. The Lancet, 384(9943), 618-625. https://doi.org/10.1016/S0140-6736(14)61217-4

Rochlani, Y., Pothineni, N. V., Kovelamudi, S., \& Mehta, J. L. (2017). Metabolic syndrome: pathophysiology, management, and modulation by natural compounds. Therapeutic Advances in Cardiovascular Disease, 11(8), 215-225. https://doi.org/10.1177/1753944717711379

Rossi, F. E., Fortaleza, A. C. S., Neves, L. M., Buonani, C., Picolo, M. R., Diniz, T. A., Kalva-Filho, C. A., Papoti, M., Lira, F. S., \& Freitas, I. F. (2016). Combined Training (Aerobic Plus Strength) Potentiates a Reduction in Body Fat but Demonstrates No Difference on the Lipid Profile in Postmenopausal Women When Compared With Aerobic Training With a Similar Training Load. Journal of Strength and Conditioning Research, 30(1), 226-234. https://doi.org/10.1519/JSC.0000000000001020

Schroeder, E. C., Franke, W. D., Sharp, R. L., \& Lee, D. (2019). Comparative effectiveness of aerobic, resistance, and combined training on cardiovascular disease risk factors: A randomized controlled trial. PLOS ONE, 14(1), e0210292. https://doi.org/10.1371/journal.pone.0210292

Schwingshackl, L., Missbach, B., Dias, S., König, J., \& Hoffmann, G. (2014). Impact of different training modalities on glycaemic control and blood lipids in patients with type 2 diabetes: a systematic review and network meta-analysis. Diabetologia, 57(9), 1789-1797. https://doi.org/10.1007/s00125-014-3303-z

Shimojo, G. L., Silva Dias, D. da, Malfitano, C., Sanches, I. C., Llesuy, S., Ulloa, L., Irigoyen, M.-C., \& De Angelis, K. (2018). Combined Aerobic and Resistance Exercise Training Improve Hypertension Associated With Menopause. Frontiers in Physiology, 9(OCT). https://doi.org/10.3389/fphys.2018.01471

Son, W. M., Sung, K. D., Cho, J. M., \& Park, S. Y. (2016). Combined exercise reduces arterial stiffness, blood pressure, and blood markers for cardiovascular risk in Postmenopausal women with hypertension. Menopause, 24(3), 262-268. https://doi.org/10.1097/GME.0000000000000765

Srivastava, R. A. K. (2018). Dysfunctional HDL in diabetes mellitus and its role in the pathogenesis of cardiovascular disease. Molecular and Cellular Biochemistry, 440(1-2), 167-187. https://doi.org/10.1007/s11010-017-3165-z

Stefanska, A., Bergmann, K., \& Sypniewska, G. (2015). Metabolic Syndrome and Menopause. Advances in Clinical Chemistry, 72, 1-75. https://doi.org/10.1016/bs.acc.2015.07.001

Stratton, I. M., Adler, A. I., Neil, H. A. W., Matthews, D. R., Manley, S. E., Cull, C. A., Hadden, D., Turner, R. C., \& Holman, R. R. (2000). Association of 
Research, Society and Development, v. 10, n. 8, e52810817571, 2021 (CC BY 4.0) | ISSN 2525-3409 | DOI: http://dx.doi.org/10.33448/rsd-v10i8.17571

glycaemia with macrovascular and microvascular complications of type 2 diabetes (UKPDS 35): Prospective observational study. British Medical Journal, 321(7258), 405-412. https://doi.org/10.1136/bmj.321.7258.405

Vistisen, D., Witte, D. R., Brunner, E. J., Kivimäki, M., Tabák, A., Jørgensen, M. E., \& Færch, K. (2018). Risk of Cardiovascular Disease and Death in Individuals With Prediabetes Defined by Different Criteria: The Whitehall II Study. Diabetes Care, 41(4), 899-906. https://doi.org/10.2337/dc17-2530

Zaw, J. J. T., Howe, P. R. C., \& Wong, R. H. X. (2018). Postmenopausal health interventions: Time to move on from the Women's Health Initiative? Ageing Research Reviews, 48(October), 79-86. https://doi.org/10.1016/j.arr.2018.10.005 